\title{
Exploring the Roles of Grassroots Organizations as Potential Agency: The Case of Chittagong Hill Tracts, Bangladesh
}

\author{
Choudhury Farhana Jhuma ${ }^{1}$, Sanjay Krishno Biswas ${ }^{2}$ \\ ${ }^{1}$ Associate Professor, Department of Anthropology, Shahjalal University of Science and Technology, Sylhet, Bangladesh \\ ${ }^{2}$ Assistant Professor, Department of Anthropology, Shahjalal University of Science and Technology, Sylhet, Bangladesh \\ DOI: https://dx.doi.org/10.47772/IJRISS.2021.5420
}

\begin{abstract}
The Chittagong Hill Tracts (CHT) region of Bangladesh represents the close combination of the settlements of several indigenous communities, and the communities have the specific socio-economic tradition; the influence of colonial administration, national bureaucratic domination, neo-liberal promise, and frequent policy regulations in the issues relating to their right to the ownership of land. Considering the historical conflicts and reality, the area is composed of various voluntary and profit-based organizations that aim to provide livelihood and capacity enhancement support to the co-existing indigenous peoples. From the ground of the structural development initiatives and learning, the study examines the pattern of ongoing grassroots organizations led by indigenous people in the CHT, their limitations, and the initiatives taken by them. The paper aims to analyze the role of micro-organizational development in addressing the socio-political emphasis in the CHT during the study period (June 2018 to December 2019). Although the studied organizations are concerned with particular social needs and most of them are in the legal framework, the internal network has several concerns, including rights of land, language, empowerment, poverty, and gender, religion, and settlement issues in the CHT Adivasi context. The study was conducted in three CHT districts-Rangamati, Bandarban, and Khagrachhari-taking two upazilas (subdistricts) from each district. The study follows qualitative analysis; the grassroots organizations have been categorized on a sector-wise basis to explain the needs and functions of the organizations. Moreover, the study proposes the possible alternatives in the cohesion to the formation of inter-ethnic identity by analyzing the activities of the small-scale indigenous organizations in the CHT.
\end{abstract}

Keywords: The Chittagong Hill Tracts, Grassroots organization, Development initiatives, Social cohesion, Identity

\section{INTRODUCTION}

$\mathrm{U}$ nderstanding the concerns of the indigenous people of Bangladesh is relevant from significant socio-political aspects. The paper follows the colloquial fix Adivasi as indigenous, keeping in mind the elaborate meaning of legal and cultural homogeneity from the enlarged meaning of the UN declaration 1993, away from the definitional meaning of the political practice of Bangladesh regarding the concept ${ }^{1}$.

1'Tribal' identity was introduced in the 15 th amendment of the national constitution in 2011 for the Adivasi of the CHT besides the dominant non-
Prashanta Tripura (2015) has addressed the prevailing twofold meaning of indigenous identity discourse - nationalist and socialist, and remarks that the focus has to be on rethinking dependency on national and international power group and concentrating on the consciousness of being indigenous in terms of unity on a common interest (Platform of indigenous right; land, economy, culture).

In the nationalist context, looking for originality in settlement for civil rights is a scholarly debate (Brubaker 1998). Bangladesh's mainstream political stand regarding indigenous communities' living account in CHT has shifted eventually (Gerharz 2014). Moreover, currently, the right of the indigenous people is a global concern; the patterns vary according to regional, national, or global emphasis (Dhamai 2014). Denial Mato (2000) exemplifies the role of intermediate NGOs in the Amazon basin states that multinational and transnational organizations are making for social representation of identities and needs through the culture and ideology of founder and fund providing countries of the agencies. Eventually, the multinational engagement in the development sector for subsidizing in economic, capacity built, and human rights are not above question. On evaluating the development initiatives undertaken for the CHT indigenous people, identity crises have been recognized as a vital issue for social deprivation and socio-economic drawbacks (Dhamai, 2014). Access to land, literacy, livelihood, and Bengali settlement is typical among much other unsolved struggles in CHT (Chakma and Maitrot, 2016). With the increase of voluntary, aid-based, and vocational organizations in the CHT, the judgments of the beneficiaries are growing on the policy framework. Now, it is time to revise the policy framework by academic and professional network between development agents (UN, United Nation Draft Declaration on the Rights of Indigenous People UNDDRIP) and dominating power groups (State and NGOs). The study focuses on the role of indigenous grassroots organizations in

tribal Bengali living in CHT (Dhamai B. M. 2014, p. 21). Here khudrojatishotta and upajati also carry the same meaning to address the ethnic minority of Bangladesh, including the Adivasi of CHT. The critics of the 'tribal' identity have not elaborated here on the irrelevancy of the article's subject matter. 
CHT to address the local people's perception of socioeconomic and human rights issues and pattern of networking for the common need of self and community wellbeing. Furthermore, the study reflects the pattern of nctional cohesion based on the grassroots organization in CHT.

The research focuses on the function of grassroots organizations in CHT, the approach influenced by global strategy shift of development priority, [Elizabeth Colson addressed McNamara's "building up of the countryside" as 'dramatic shift of development strategy" at the late 1970s, and global importance of NGO became evident in the 1980s and onward (Cernea 1988 in Smith 1996). The CHT treaty is another important event of discussion]. The study finds that an alternative, and development offshoot framework of grassroots organization in the CHT is forming among the indigenous people of different identities through a functional unity of socio-economic experience and goal; omitting standardization by genealogy, settlement root, and civil tradition. The self-driven initiatives by the organizations of indigenous people in the CHT can explain the contemporary trend of policy endorsement and the formation of networking of such organizations, with emphasis on analysis of diversified employment needs of indigenous people of CHT.

The argument follows the steps of ascertaining the visible role of 'grassroots organizations' commonly found as cooperatives, based on market demand and social awareness programs and identifying the grassroots organizations working in the locality. The process will reveal the missing links of development priorities and demonstrate the potentiality of grassroots-level organizations in the CHT.

\section{CONCEPTUALIZING THE ISSUES}

Tripura (2015) opined that there is a dilemma of development, both in practice and paper, and suggesting the development, particularly in the CHT area, is still an ambiguous for organization, people, and power groups. The continued onside service rendering and regulating policy has made the development a critical process. The government and nongovernment efforts are still in long and short-term projectbased experiments synonymous with irregular activity and follow dominating 'demand and planning' (Tripura, 2015). The prevalence of the 'market economy' (Tripura 2015; Nasreen and Togawa 2002) is the existing reshaping force in formulating mainstream expectations. The need for agendabased development is approaching in development planning for the wellbeing of indigenous people. Here, with the gaze at the global academic and professional shift in development initiatives, the feedback from beneficiaries comes forward as an uplifting concept.

In supporting an alternative framework for indigenous social organization, from the perspective of Oceanian indigenous reality, Sewabu and Tapiata (2012) pay attention to the gap between understanding of social 'protection' and 'wellbeing' by indigenous groups and mainstream development policymakers; the two concepts carry two different meanings and have been separated as collective freedom vs. individual freedom. Modern wellbeing mechanism depends on individual development, whereas the indigenous socio-cultural aspect is formed as a collective improvement. Durie (2005b), cited in Sewabu and Tapiata (2012), addresses three essential components for local organizations such as full participation, access to indigenous culture through indigenous people, and equality in framing the alternative framework for indigenous organizations. Sewabu and Tapiata, 2012 continues that the general pattern of social protection as a 'formal system' includes livelihood training, insurance, empowerment, and poverty alleviation that is concentrated on 'material deprivation' whereas the 'informal' social protection connotes culture, social relations, and networks remain ignored in addressing indigenous communities.

The social development initiatives depends upon considering the indigenous community as similar and conventional. In the case of the CHT, particularly after the Accord signed in 1997 since the indigenous communities of the region have concerns about various political, mainstream humanitarian, and critical contexts. This is well-known that national and international organizations have long-standing activities in the CHT region that have also been accelerated after the CHT Accord. With their initiatives, a handful of local and grassroots-level organizations have emerged and replaced the traditional organizations in some cases. The agencies concentrate on the impact of development on indigenous people. The present study explores the activities and potentialities of grassroots organizations in the $\mathrm{CHT}$ region of Bangladesh, where some are involved with income-generating activities and others with human rights initiatives. Moreover, the presence of multiple communities and Bengali-ethnic composition is an inevitable reality in the area exposed in the study.

\section{POPULATION COMPOSITION AND DEVELOPMENT PATTERN: THE HISTORY OF DEPRIVATION}

Eleven ethnic communities inhabit the Chittagong Hill Tracts region with distinct cultures (Gain 2011). The eleven ethnic groups with 592,977 are Chakma, Marma, Tanchangya/Dengnak, Tripura, Pangkhua, Lushai, Khumi, Khyang, Mro, and the Chak, or Sak (Gain 2011). It is claimed that the Bangalee population is increasing gradually, which was $2.5 \%, 10 \%, 35 \%$, and $67.95 \%$ in $1947,1951,1981$, and 1991 respectively (Gain 2011). The Chittagong Hill Tracts region consists of three administrative districts: Rangamati, Khagrachhari, and Bandarban, previously part of the Chittagong administrative district [The increasing trend of Bengali people in the CHT compels the policy-makers to include Bengali population along with the indigenous community in imposing any laws, regulations, and ordinances].

Historically, the British colonizers exploited the communal land-use arrangement on the CHT to establish supreme and unlimited authority over the land, and, hence, the hill slopes became the property of the state. The hilly people continued to 
engage in shifting cultivation, but they levied a jhum tax to encourage them to shift the sedentary agriculture. After 1947, the Pakistan Government established three mega-projects that hampered the life and livelihood of the CHT people. Since its establishment, the paper mill has procured millions of tons of bamboo and softwood. After a few years of these projects, the Kaptai Hydroelectric Project (a Pakistani symbol of development) created a 650 sq. $\mathrm{km}$. upstream reservoir, submerging $40 \%$ of the CHT's most fertile valley, many villages, and forests. It displaced around 100,000 people who constituted one-quarter of the region's population (Gain 2000). Many of those displaced had no other choice left but to push up into the hills and take to jhum cultivation, which they had abandoned a long time ago [Jhum means the shifting or slashand-burn cultivation. The indigenous communities of the CHT widely practice it].

The CHT Development Board was formed in 1976 [Chittagong Hill Tracts Development Board Ordinance, 1976 was enacted in the same year] to make more exceptional and planned development in the area. An amendment to Rule 34 of the CHT Manual in 1979 lifted the restriction against the CHT land settlements by non-residents [The 1976 Ordinance was replaced by the Chittagong Hill Tracts Development Board Law, 2014 and directed the functions, working area of its Chairman, Vice-Chairman, and members. The functions of the board include at undertaking projects and schemes, approval of schemes and projects under Tk. 2 crores, implementation of different projects of other development agencies, and so on. The law gives scope to include more bureaucrats in the development process of $C H T]$. In the early eighties, around 400,000 Bengali people settled in the CHT, and with this process, many indigenous people had to be displaced from their living places.

Furthermore, around 100,000 hilly and indigenous people were ejected under the settlement policy from their traditional land. About half of them became refugees in India, and half got scattered throughout the CHT to become internallydisplaced persons (Gain 2000). The process enhances the deprivation and, as a result, land rights, along with other human rights issues, became part of the everyday struggle of the indigenous community of the CHT.

On the other hand, the development pattern has gained the a remarkable shift after the CHT treaty signed in 1997, and the approach, goal, and beneficiary have newly emerged with the networking of external influence and thinking. The aid-based policy framework by implementing the NGO concept has reshaped the development scenario of $\mathrm{CHT}$, and the local agent has entered into the market-centric development force. The post-treaty reformation policy has turned the NGO-based development process dependents on national legitimacy and international fund in major. With the new policy transformation, community-based voluntary and non-profit organizations in CHT has turned into profit and salaried project-driven local NGO's; the case of humanitarian foundation partnership with DANIDA are among many other in late 90's of signing CHT treaty, (Chakma 2019, p. 354). The fund-based agencies remained concerned to networking and matching the interest of NGO- credit-based income generating program and concern on human rights issue of the changing time (1990's 'new policy agenda' of donor agencies of international sectors). The Government-NGO-Civil society dynamics became a concern overshadowing the good work potential of NGOs and external agencies in Bangladesh after the post-treaty period. The bureaucratic regulation has holt the development prospect pushed by NGOs, led by internal and external organizations. The projects were left short due to uncertainty of aid and fund. According to David Lewis (1997), the civil society role of NGOs has never been that successful in Bangladesh because of underlying social, economic, and political interest and dependency of NGOs on state and donor source. In explaining the peacebuilding function of NGOs in CHT, Chakma (2019) narrate that the 'risk of sustainability' of NGOs are fund uncertainty and internal and external interest, government officials interruption, mistrust and profit and fund share culture among the NGO staffs and corporate groups. The abduction of DANIDA (Danish International Development Agency) staff in 2008 in Bandarban, 2001 in Rangamati by external-local insurgents (Chakma 2019, p.308) have discouraged foreign involvement in CHT. The HTNF (the Hill Tracts NGO forum) is working to gain the government's confidence regarding the NGO activities 'sensitivity' in CHT, even in playing a complementary role in the human development field. All the complexities has reduced the potential rise and sustainability of NGO programs in CHT.

\section{CHT TREATY IMPLEMENTATION: POLITICAL AUTHORITY AND COMPLEXITIES IN SOCIAL COHESION}

The CHT is customarily divided into several circles (Chiefheaded), Mouzas (Headman or Dewan-headed), and Paras (Karbari-headed) as done in 1881 by the Government of Bengal. The circles are Chakma Circle, Bohmang Circle, and Mong Circle. The chiefs and headmen were usually hereditary. Although the circle chiefs and headmen maintained the regulations, all the powers (executive, judiciary, and financial) were vested in Deputy Commissioner (DC) [Article 7 of Chapter III placed the CHT under the DC's administration, empowered with extra-ordinary power]. On February 15, 1972 [after the Liberation of Bangladesh], a delegation of hilly people led by M N Larma placed the four significant demands to the Government for the autonomy of the CHT people. By the mid-1980s, the Parbatya Chattogram Jana Sanghati Samity (PCJSS) began using the term 'Jumma Nationalism' to counter the hegemony of Bangladesh State and unify the different groups in the CHT. After a longstanding battle between Shanti Bahini (a section of PCJSS), Bangladesh Government opened up the Peace Accord signed in December 1997.

The long-cherished CHT treaty had opened up the space of equal rights and participation of Adivasi from policymaking 
to grassroots level capacity enhancement initiatives, reflected in clauses and amendments clustered in four different sections (UCDP Chittagong Hill Tracts Peace Accord manual 1997). The Chittagong Hill Tracts Regional Councils 1998, chaired by an elected tribal representative to coordinate the existing three Districts councils of Rangamati, Bandarban, and Khagrachari, has brought new hope in the CHT tribal reality. The framework of the administrative body has reflected the ethnic diversity and demand of the participatory working body of the CHT leaders [the actual demand was 'regional autonomy' by the PCJSS]. The Land Commission has been established with the clause of ensuring the supremacy of Reginal Council by land dispute settlement (Article D.2 in GI 2001, p. 17) and recognizing the traditional, communal, and customary laws practiced in CHT [though Land Commission is yet to start working independently since its existence in 2000]. Moreover, the Ministry of CHT Affairs (MoCHTA) has been formed to supervise CHT issues. The local tribal administration has been assured upon withdrawing the military camp inside the village and close vicinity of tribal inhabitants. The culture, religion, and capacity building of Adivasi has been emphasized with linguistic autonomy and government funding and scholarship to enhance employment and job access following the rehabilitation of both internal and external IDPs (Internally Displaced Population). As the CHT Accord is still unimplemented, numerous issues have arisen, such as political empowerment, parallel administration, and lack of coordination regarding politics of the indigenous communities (political rights). The experience of CHT treaty implementation in twenty-two years shows that the regional council cannot practice the dominant role in the redistribution of khas land, IDPs issue settlement, customary land distribution complexity solution, and election for change of authority. The effort has been marked as ' 25 provisions has only been implemented out of 72 clauses and 34 provisions remain unimplemented with 13 partial implements' (J. Tripura 2019, The Daily Star). On the other hand, some rivalry groups emerged as most of the issue of the CHT Accord has not been implemented yet. Some other organizations like United Peoples Democratic Front (UPDF), PCJSS (Larma), and Ganatantric UPDF, who are competing with each other now and sometimes their faction stands as an insurgency to ensure the rights of indigenous people.

\section{METHODOLOGICAL CONSIDERATION}

The data collection has been conducted in Kaukhali and Sadar Upazila of Rangamati, Lama, Sadar Upazila of Bandarban, and Sadar and Panchhori Upazila of Khagrachhari district in June 2018-December 2019 periodically and is financed by the research center of Shahjalal University of Science and Technology, Sylhet. Bangladesh. The respondents were sampled from different communities, like Chakma, Tripura, Marma, Tanchyanga, Mro and Bengali. All respondents are within the category of beneficiaries, gatekeepers, or members of grassroots-level organizations in the locality. The study took 12 (twelve) organizations and their beneficiaries (see the table below). The respondents have been selected through the purposive and snowball sampling technique. Six gatekeepers from six Upazilas have been selected as key informants. Three focus group discussions (FGDs) were conducted, including one from each district, which included categories of people according to the membership in the organizations. Information was collected on their respective organizational activities and benefits they received and how these were different from other macro-level organizations. The study conducted thirtysix in-depth interviews to ask about people's personal experiences and involvement with grassroots organizations. The necessary literature and studies regarding the CHT have been reviewed to accomplish the study. The demography of the respondents is focused on indigenous, educated, have engagement with broader organizations, get training, have skills, entrepreneur experience, service, and common saving members. 8-10 respondents have been selected from each grassroots organization for creating a sample size. The grassroots organization has been selected from Upazila, union, and para (local social, administrative unit) to get the rural and semi-urban functions of grassroots organization in the study area. $41.4 \%$ of the study area submits their report on cooperatives and government offices and seek legal support for expansion of the organizations.

\section{RESULTS AND DISSUASION}

\subsection{History and Structure of Grassroots Organizations in the CHT}

On behalf of a community or organizer of the community itself, the grassroots organizations involve community people for advocacy (Foster and Louie 2010). With the multifaceted activities ranging from agriculture to empowerment, the nature and structure of grassroots organizations have two lenses of analysis: capacity-building and organizing community. The CHT accepts the resemblance of dropout impact of the development endeavors in organizational, individual, and group-based functioning. With a structured and progressive work-plan, some dominant organizations develop a national policy framework and motivate indigenous people for betterment. However, all the grassroots organizations merely comply with the national development priority; instead, they concentrate on local needs. The grassroots organizations of the CHT have two categories: some of them should deliver aid, and services to the community and others have aimed at commercial purposes after mitigating their own needs. There are numerous international and national organizations active in the CHT, especially after the treaty was signed. They are motivating people to organize and build their capacities to maintain their livelihood activities, and very few are motivating people about their right-based issues, such as rights over land and other political rights.

The leadership framework has suggested "indigenous community capacity-building" privileges, community ownership, and self-governance, reflecting on decisionmaking and action (Foster and Louie 2010 and Taylor 2003). 
In the CHT, this formation is happening across the three districts. For example, Dinachan Para Unnayan Samity is a grassroots-level organization that works at Panchhari Upazila in Khagrachhari hill district. This Samity is a Chakma community-based organization formed in 2012 under a UNDP (United Nations Development Program), project namely 'Peoples' Empowerment Project. The UNDP gave financial and technical support to promote their income-generating activities, such as honey production, sugarcane cultivation, and nurseries, during the commencement of the organization. Although the members are continuing their role in the organization, they merely apply their knowledge gained from the training earlier. This Samity also has a women wing in the area. Here, capacity-building and community-organizing activities occurred with the initiative of external forces around the CHT. Although the capacity-building helps restore people's future, it reduces the traditional relationship of the people with nature and makes them reluctant towards their socio-political rights.

On the other hand, some grassroots-level organizations were formed by some potential leaders. The leadership in community-based organizations depends on communityinitiated processes, such as oral culture, rituals, and direct action (Foster and Louie 2010). For instance, Suman Chakma is a potential leader who worked for several NGOs for many years got knowledge from some UNDP projects and another local NGO. After some years, his relationship with the local people enhanced to form a grassroots-level organization for livelihood activities. He formed a 34-membered organization, namely Khagrachhari Mouchashi Kalyan Samity, to provide financial and technical support to its member. The organization comprises the indigenous (Chakma, Marma) and (Bengali), and members are bonded with mutual obligation, norms of the social network. Some leaders think that the presence of an enforced mainstreaming process enacts in the locality, making people of the area deprived in every sense. Most people survive with their limited or no access to land and other resources, reluctance over CHT Accord, and other external forces.

\subsection{Diversity in Activities and Management of Organizations}

In indigenous communities, collective responsibility and mutual obligation rather than individual rights are generally emphasized (Esteva 2006). In the CHT region of Bangladesh, the community decision is considered an outcome of consensus. The traditional political authorities were once the sole decision-making bodies in the particular locality. However, the presence of settlements and the effectiveness of several projects make the area unable to keep homogeneity in the decision-making and resource extraction process. Since the Bengali settlement delimits access to resources, it also hampers mutual interest, shared values, and perceived knowledge. Many factors are contribute to the emergence of grassroots organizations, which include the increased heterogeneity, mistrust among local political groups, delaying of implementation of the CHT Accord, and the increase of law-enforcing agencies in the areas. However, the similarities and differences among grassroots-level organizations are aligned with their origin, activities, and areas of concentration. The following table represents the similarity and differences of the studied organizations:

Table: Grassroots and Community-based Organizations

\begin{tabular}{|c|c|c|c|c|c|c|}
\hline $\begin{array}{l}\text { Organization/ } \\
\text { District } \\
\text { (Year of founding) }\end{array}$ & $\begin{array}{l}\text { Type (self- } \\
\text { described) and no. } \\
\text { of members }\end{array}$ & $\begin{array}{l}\text { Legality/ } \\
\text { Registration } \\
\text { Authority }\end{array}$ & Aim and purpose & $\begin{array}{l}\text { No. of } \\
\text { communit } \\
\text { ies } \\
\text { involved } \\
\end{array}$ & Funding sources & Decision-makers \\
\hline $\begin{array}{l}\text { Jagroto kallyan Samity, } \\
\text { Bandarban (2015) }\end{array}$ & $\begin{array}{l}\text { Community-based } \\
\text { organization } \\
\text { Member-52 }\end{array}$ & No & $\begin{array}{l}\text { To organize religious } \\
\text { (community) ceremonies } \\
\text { and savings }\end{array}$ & Three & $\begin{array}{l}\text { Members' } \\
\text { subscriptions }\end{array}$ & $\begin{array}{l}\text { Executive } \\
\text { Committee }\end{array}$ \\
\hline $\begin{array}{l}\text { Roangchari Mahila Samity, } \\
\text { Bandarban (1994) }\end{array}$ & $\begin{array}{l}\text { Women support } \\
\text { Member-50 }\end{array}$ & Yes & $\begin{array}{l}\text { To support destitute } w \\
\text { omen through financial and } \\
\text { technical assistance }\end{array}$ & One & $\begin{array}{l}\text { Members' } \\
\text { subscriptions, } \\
\text { Govt. support }\end{array}$ & $\begin{array}{l}\text { Executive } \\
\text { committee }\end{array}$ \\
\hline $\begin{array}{l}\text { Nabanno Mahila Samity, } \\
\text { Bandarban (2016) }\end{array}$ & $\begin{array}{l}\text { Women support } \\
\text { Member- } 41\end{array}$ & Yes & $\begin{array}{l}\text { To support women in } \\
\text { disaster and employment } \\
\text { generation }\end{array}$ & Two & $\begin{array}{l}\text { Members' } \\
\text { subscriptions, } \\
\text { Govt. support }\end{array}$ & $\begin{array}{l}\text { Executive } \\
\text { members }\end{array}$ \\
\hline $\begin{array}{l}\text { Alav Rang, Bandarban } \\
\text { (2014) }\end{array}$ & $\begin{array}{l}\text { Youth organization } \\
\text { Member-10 }\end{array}$ & No & $\begin{array}{l}\text { To organize youth people } \\
\text { and provide free tuition to } \\
\text { poor students }\end{array}$ & One & Self-donation & $\begin{array}{l}\text { Executive } \\
\text { committee }\end{array}$ \\
\hline $\begin{array}{l}\text { Jubo Unnoyon Samity, } \\
\text { Rangamati (2017) }\end{array}$ & $\begin{array}{l}\text { Youth training and } \\
\text { income generation } \\
\text { Member-35 }\end{array}$ & No & $\begin{array}{l}\text { To support in agriculture, } \\
\text { especially sericulture } \\
\text { (Reshom) and hatchery }\end{array}$ & One & $\begin{array}{l}\text { Government } \\
\text { support }\end{array}$ & General members \\
\hline $\begin{array}{l}\text { Kalyanpur Bijhu Samity, } \\
\text { Rangamati (2016) }\end{array}$ & $\begin{array}{l}\text { Festival } \\
\text { arrangement } \\
\text { Member-15 }\end{array}$ & No & $\begin{array}{l}\text { To provide loan and bonus } \\
\text { in Bijhu festival }\end{array}$ & One & $\begin{array}{l}\text { Donation and } \\
\text { member's savings }\end{array}$ & $\begin{array}{l}\text { Executive } \\
\text { committee }\end{array}$ \\
\hline $\begin{array}{l}\text { Daksin Debotachori Chatro } \\
\text { Kallyan Samity, Rangamati } \\
\text { (1995) }\end{array}$ & $\begin{array}{l}\text { Educational support } \\
\text { Member-52 }\end{array}$ & No & To support poor students & One & $\begin{array}{l}\text { Members' } \\
\text { monthly } \\
\text { subscriptions }\end{array}$ & $\begin{array}{l}\text { General } \\
\text { Committee }\end{array}$ \\
\hline $\begin{array}{l}\text { Upojatio Kath O Joth Malik } \\
\text { Samity, Rangamati } \\
\text { (1994) }\end{array}$ & $\begin{array}{l}\text { Farmers and labor } \\
\text { right awareness } \\
\text { Member-123 }\end{array}$ & Yes & $\begin{array}{l}\text { Agricultural support and } \\
\text { awareness }\end{array}$ & Three & $\begin{array}{l}\text { Members' } \\
\text { savings and tax } \\
\text { from vehicles }\end{array}$ & $\begin{array}{l}\text { Executive } \\
\text { committee }\end{array}$ \\
\hline
\end{tabular}




\begin{tabular}{|c|c|c|c|c|c|c|}
\hline $\begin{array}{l}\text { Khagrachhari Mochasi Kalyan } \\
\text { Samity, Khagrachhari (2015) }\end{array}$ & $\begin{array}{l}\text { Honey-producing } \\
\text { Member-36 }\end{array}$ & No & $\begin{array}{l}\text { To provide support for } \\
\text { honey production }\end{array}$ & Four & $\begin{array}{l}\text { Members' } \\
\text { monthly } \\
\text { subscriptions, } \\
\text { external support }\end{array}$ & $\begin{array}{l}\text { Executive } \\
\text { committee }\end{array}$ \\
\hline $\begin{array}{l}\text { Dinachan Para Unnayan } \\
\text { Samity, Khagrachhari (2009) }\end{array}$ & $\begin{array}{r}\text { Financial } \\
\text { assistance }\end{array}$ & No & $\begin{array}{l}\text { Counseling and financial } \\
\text { assistance to the members' } \\
\text { families }\end{array}$ & One & Monthly savings & $\begin{array}{l}\text { Executive } \\
\text { committee }\end{array}$ \\
\hline $\begin{array}{l}\text { Ohingsha Samabay Samity, } \\
\text { Khagrachhari(2012) }\end{array}$ & $\begin{array}{l}\text { Financial assistance } \\
\text { in the business } \\
\text { sector } \\
\text { Member }-250\end{array}$ & Yes & To give a loan and savings & One & $\begin{array}{l}\text { Members' } \\
\text { subscriptions }\end{array}$ & $\begin{array}{l}\text { Executive } \\
\text { committee }\end{array}$ \\
\hline $\begin{array}{l}\text { Nion Karbaripara Unnayan } \\
\text { Samity, Khagrachhari(2008) }\end{array}$ & $\begin{array}{l}\text { Agricultural } \\
\text { training } \\
\text { Member - } 64\end{array}$ & Yes & To provide loan and training & One & $\begin{array}{l}\text { Donor support } \\
\text { and members' } \\
\text { subscriptions }\end{array}$ & $\begin{array}{l}\text { Executive } \\
\text { committee }\end{array}$ \\
\hline
\end{tabular}

(Source: Fieldwork 2019)

The grassroots organizations taken in the study have both the characteristics of the community capacity-building model (CCM) and the community capacity restoration model (CCR), which was developed by Evans (2020). Briefly, the CCM model provides the arenas for formulating shared values and preferences and instruments for pursuing them, whereas CCR model is designed for community capacity for action, agency, and exercise of social control of the community. Most of the organizations depend on the executive committee or heads of the organizations in the decision-making process, and a few have the scope to depend on the general members through participation. As the significant numbers have initiatives regarding credit and income-generating activities, they have definite relations with a formal market system that carries the characteristics of CCM. Like Alav Rang of Bandarban and Daksin Debotachori Chatro Kallyan Samity of Rangamati have programs, like organizing the youths and supporting the poor students through tuition and scholarships, which comply with the CCR model. Only one organization-Jagrata Kalyan Samity of Bandarban - has some spiritual initiatives among its members. Both of the abovementioned models abide by the rules of citizens, community, or indigenous people's rights. In the CHT context, the nature of these grassroots organizations does not necessarily respond to inheriting issues, like rights over land, violation of human rights, and related issues. However, their potentiality cannot be ignored in raising voices in case of different human rights-related issues, like eviction from living land, inter-community conflict, and filing cases in police stations. Although only five among twelve organizations have legal affiliations with different government authorities, such as Directorate of Social Welfare, Directorate of Youth Development, and Directorate of Cooperatives, all the organizations have networking and possibilities to cope with the historical and contemporary issues in the CHT.

\subsection{Internal and External Networking of Grassroots Organizations}

Though the international instruments are activated in these organizations, the legitimacy for promoting and protecting the rights of indigenous people cannot be overlooked. The organizations and their leadership actively engaged in numerous symbolic and resource transactions with various global agents (Mato 2009). Some grassroots organizations in the CHT region comprises one community. Alav Rang is a youth-based organization that consists of the Marma community, and this organizes its work in Roangchari, Bandarban. This organization provides free tuition support to poor Marma students and organizes the youths. People identified torture and murder as major human rights violations in the locality, although they discuss their rights over land and other socio-political issues. As respondents viewed, the lack of mobilization and responsibility, lack of appropriate policy, and even non-cooperation from the community is crucial for chaotic situations among the community people. Other impacting factors include internal and intra-ethnic conflict, mistrust among communities, and political factions.

Grassroots organizations visibly operate the livelihood programs, such as income-generating activities and reducing related social problems. They work in more than a single community. Therefore, internal communication among the communities and geographical inhabitancy is critical to forming the organizations. In some cases, the leader's charismatic character and trustworthiness might help the formation of the organization. For example, the President of Khagrachhari Mochashi Kalyan Samity motivated 36 people from Chakma, Marma, and Hindu and Muslim communities to get them involved with honey production. $\mathrm{He}$ communicated and maintained networks with businesspeople in Dhaka, Rajshahi, Chittagong city, and Sylhet. He managed to convince the businessmen to buy the products (honey) every month from the members of the Samity.

The grassroots-level organizations with legal registration get direct financial and technical support from the Government through three CHT Development Boards (based in Rangamati, Khagrachhari, and Bandarban) with different projects. Besides, both registered and non-registered organizations get financial and technical support from international donor agencies, like UNDP, ADB, DANIDA, and CARE as well as National NGOs, like BRAC, ASA, MJF, and IPDS [UNDP, ADB, DANIDA, CARE are the international agencies working globally; BRAC and ASA are mainly micro-credit organizations, although they have socio-economic projects. Moreover, MJF is a human-rights and governance-based donor organization, and IPDS works to develop the indigenous community in Bangladesh. Non-registered 
organizations get only technical support from government entities, whereas some are in the registration process. On the contrary, some grassroots organizations are unwilling to register with government entities to work independently. Some of them are directly connected to local and national markets, which serve the development process but hinder meeting local needs. However, multi-ethnic organizations help in binding one another collectively in the locality. The outcomes of the internal and external connections of grassroots organizations might be the products of globalization, which, sometimes, has positive facets, including the construction of shared bonding, material or financial benefits from particular products, and the cognitive bonding amid homogeneity, even in heterogeneity.

\subsection{Agency and Governance of Grassroots Organizations}

The nature and characteristics of grassroots organizations (GRO) are described by Norman Uphoff (1986), and he stated the spheres of activities of both NGOs and GROs. As Uphoff (1986) mentioned, there are three types of local institutions which are active in the era of globalization: the public sector comprises local government and local administration; the collective action sector includes membership organizations and cooperatives, and the private sector is composed of service organizations and private businesses (Uphoff 1986). In the context of the CHT, the collective action sector is built based on common interests and resource-pooling through selfhelp and collective initiatives. Since the CHT region faces a social, cultural, ecological, and technical change where traditional relations had to lose importance and connectivity, an NGO or even GRO might be an adaptive strategy. Our conversations with different stakeholders explored the emergence of GROs as the outcome of external factors or actors. The financial and political vulnerability of the indigenous community helps them to organize and stay under a unique umbrella. Their activity and performance start with rituals but ends up with several rights issue regarding the livelihood strategy. Almost every GRO has a specific plan, and they start up with income-generating activities but have active participation in local-level social and political negotiations. Again, landlessness is an acute problem for some GRO members, and, in that case, the leaders of the organizations promise to support the members to get entitlement of the living place. The common scenario of the sub-urban area of every CHT district and upazila area has reflected here. One of our key informants said, "If the land commission works neutrally, we will have a chance to get a permanent living place. The survey and other relevant activities are yet to be done, but some traditional authorized areas would have changed in the context of implementation. As the organization members are not involved with large political entities, we are not directly affected, but indirect impacts happened there".

The grassroots organizations of the CHT are entirely based on voluntary participation, either kin-based or interest groupbased, and often act as part of territorial units. It, as Kerri noted, might be a transition from the traditional way of livelihood to modern techno-based survival under certain conditions of change, the basis of organization for social groups becomes restructured around shared interests, such as occupation, profession, recreation, or spirituality, which provide the means for social groups to adapt or reform to new urban contexts (Kerri 1968). Considering the nature and activities of a grassroots organization, it acts as an agency of civil activity towards its members, and they must obey its principles. The connectedness of grassroots organizations in the CHT with a government entity directs the legislative process. Hence, an individual's performance under community-based organizations resembles CHT's principal concerns, such as delay of implementation of the CHT Accord and other unresolved issues, including rights over land. In that case, grassroots organizations stand behind the community members as their safeguard, and our study explores the potentiality of these organizations as the mentors of advocates in case of human rights and humanitarian issues.

\section{CONCLUSION}

The article has explained the need for community-based grassroots organizations in the changing internal and external socio-political context of CHT. After the CHT Treaty, the gap between expectation and application of NGO-based peacebuilding activity has reshaped the necessity of indigenous community-based development. Meanwhile, foreign involvement and funding have been disrupted for overlapping of the bureaucratic approval procedure. The provision of CHT treaty implementation, such as education, health care, and women and child issues, has dependent meaningfully on CHT's internal stability and foreign funding (GI 2001, p. 24). Since the post-treaty, the involvement of modern visionaries regarding culture and identity and livelihood planning has demarcated the Adivasi of CHT as urban elites, rural cultivators, and tribal context. Development agencies, both external and internal, have also attempted to reshape CHT according to the global and national perspective and approach a development, unfamiliar to the culture and livelihood of CHT Adivasi (GI 2001, P. 24). The study reflects the local initiatives to maintain the felt-need, such as youth and women income generation, religious festival, and training utilization. The delay in implementing the CHT accord regarding the administrative and land issues has to problematize the economic and legal aspects of self-driven community-level initiatives.

In general, the need for grassroots organizations has been increased to maintain, 'savings mentality' and other necessities [According to Cernea (1988), "the essence of the NGO approach is to mobilize people to organize structure...for self-reliance and self-development" (Smith, A. Carol 1996: 27)]. In the CHT, patronization by national and international organizations and community leaders influenced the formation of grassroots organizations though they have not direct participation in the political process; they are recognized as CSOs (Civil Society Organizations). By 
explaining the complexity of understanding of different agents of development, Smith, A. Carol (1996: 30) addressed that 'constituencies' 'ideology' and 'culture' are the base of contradiction between third-world governments, first world development agent, and local people who are seeking development in the context of traditional practice. The study finds that the ongoing pattern of grassroots organization in CHT can reduce the dependency on formal NGO difficulties from an internal and external perspective and contribute to CHT's peace-building process. The organizations have concerns, awareness-raising platforms, and commitment on particular issues, but they have limited access in local ownership to land and income generation. Besides, about half of the members of the organizations from three districts have no land of their own to live in, and they live in other member's land, or government Khas land [Described as "land that vests in the Government and remains in the 'Khas possession' of the Government].

Moreover, they have applied for government land to the Ministry of Land. Some landless members viewed that they hoped to get living land from the Government if the CHT Land Commission works properly [The commission formed in 1999 follows the CHT Accord of 1997. The Government drafted the CHT Land Disputes Resolution Commission Act in 2001, and some provisions of the ACT were amended in 2016]. In that case, the particular grassroots organization acts as a safeguard for its landless members. Community leaders of the study area admit that they are living with hopes of getting rights over land, and through this achievement, they could manage livelihood with their efforts. However, local people are dissatisfied with the non-implementation of the Land Commission and other identical issues, such as lack of responsibilities transferred to the newly-formed Hill District Council (HDC). With this backdrop, the significant concerns that arisen in the CHT are intra-group conflicts among and between the indigenous (tribal) community and Bengali settlers and militaries. Therefore, the grassroots-level organizations in the locality have broader scopes to promote sustainable livelihood through capacity-building and organizing community by social networks of the indigenous (tribal) and other communities. They will negotiate in promoting and protecting the rights of indigenous communities when the development agencies are in the dilemma of mitigating complexities.

Here the study recommends that the Government's direct involvement in the administrative sector from land and monitoring aspects should be minimized for the autonomous development of the CHT indigenous communities. The complete empowerment of the Regional Council and Land Commission with the effective indigenous (tribal) participation and authority and the foreign involvement with national collaboration is needed to ensure the transparent and effective functioning of community-based grassroots organizations in CHT.

\section{REFERENCES}

[1]. Brubaker, Rogers (1998 January). 'Myth and Misconceptions in the study of Nationalism' in John A. Hall (ed.) The State of the Nation. Chap: 12, Pp. 272-302. University of California, Los Angeles. Accessed at: http://works.bepress.com/wrb/13

[2]. Dhamai, Moy Binota. (2014). An Overview of Indigenous People of Bangladesh (chap-1) in Prof. Mong Shanoo Chowdhury (ed.) Survival Under Threat: Human Rights Situation of Indigenous Peoples in Bangladesh. AIPP Printing Press. Thailand.

[3]. Durie, M. (2005b). Race and ethnicity in public policy: Does it work? Social Policy Journal of New Zealand, Vol.4. In Litea MeoSewabu and Wheturangi Walsh-Tapiata, Global Declaration and Village Discourses: Social Policy and Indigenous Wellbeing. 2012, p. 301-303.

[4]. Esteva, Gustavo. (2006). "The Society of the Different. Part 2: We Are People of Corn: Life, Metaphor, Autonomy Oaxaca, Oaxaca, Mexico." Motion Magazine, April 8. Online at: http://www.inmotionmagazine.com/global/gest int 2.html

[5]. Evans, S., Bahrami, H. (2020). Super-Flexibility in Practice: Insights from a Crisis. Global Journal of Flexible System Management 21, 207-214. https://doi.org/10.1007/s40171-02000246-6

[6]. Foster, Catherine Crystal, and Louis, Justin. (2010). Grassroots Actions and Learning for Social Change: Evaluating Community Organizing. Blueprint Research \& Design Inc.

[7]. Gain, Philip (1998). Bangladesh: Land, Forest, and Forest People, Dhaka, Society for Environment and Human Development (SEHD).

[8]. Gain, Philip (2000). The Chittagong Hill Tracts: Life and Nature at Risk, Dhaka, Society for Environment and Human Development (SEHD).

[9]. Gerharz, Eva. (2014). What is in a name? Indigenous identity and the politics of Denial in Bangladesh. South Asia Chronicle, p. 11537. Focus: Mapping Bangladesh Studies. University of Berlin

[10]. Kerri B.C. 1968 (2009). Experiences of Community Peacebuilding in the North Rift Region of Kenya. Retrieved from http://www.crs.org/sites/default/files/tools-research/amanimashinani.pdf.

[11]. Mato, Daniel (2000). Transnational Networking and Social Production of Representations of Identities by Indigenous Peoples' Organizations of Latin America, International Sociology, 15; 343-48. DOI: 10.1177/0268580900015002012, downloaded on July 3, 2009, from http://iss.sagepub.com

[12]. Meo-Sewabu, Litea. Walsh-Tapiata, Wheturangi. (2012). Global Declaration and Village Discourses: Social Policy and Indigenous Wellbeing. Accessed at: .https://www.researchgate.net/publication/303328384

[13]. Mohsin, Amena (2011). The Politics of Nationalism: A Study of the CHT, Dhaka, p. 466-72. University Press Limited.

[14]. Nasreen, Zobaida, and Togawa, Masahiko. (2002). Politics of Development: 'Pahari-Bangalee' Discourse in the Chittagong Hill Tracts. (Report) Journal of International Development and Cooperation, Vol.9, No.1, pp. 97-112.

[15]. Philip Gain (ed.) (2000). Survival of the fringe: Adivasis of Bangladesh Dhaka: Society for Environment and Human Development (SEHD), p. 1-26, 2011.

[16]. Smith A. Carol. (1996). Development and the State: Issues for Anthropologists. In Emilio F. Moran (Ed.) Transforming Societies, Transforming Anthropology.1996, p. 25-32. Ann Arbor: University of Michigan Press. The USA.

[17]. Tripura, Prashanta (2015), Bohujatir Bangladesh, Essays of Prashanta Tripura, Pp. 41-46. Dhaka, Sangbed.

[18]. Uphoff, Norman (1993). 'Grassroots Organizations and NGOs in Rural Development: Opportunities with the Diminishing States and Expanding Markets', World Development, Vol. 21, No. 4, pp.607-622.

[19]. Chakma, Anurag. (2019). Is NGO peacebuilding Risk-Free? A Case Study on Bangladesh. Asian Journal of Peacebuilding, Vol.

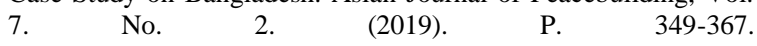
https://www.researchgate.net/publication/337916052 
[20]. Chakma, Nikhil. Maitrot, Mathilde. (2016). How Ethnic Minorities became poor and stay poor in Bangladesh: A qualitative inquiry. Working paper 34. EEP and Shiree. P. 6-18.

[21]. Lewis, David. (1997). NGO's, Donors, and the State in Bangladesh. Annals of the American Academy of Political and Social Science, The Role of NGO's: Charity and Empowerment. P. 1-8. https://researchgate.net/publication/254077417
[22]. Global IDP Database. (2002). Profile of Internal Displacement: Bangladesh. Norwegian Refugee Council/Global IDP Project. http://www.idpproject.org

[23]. UCDP (Dec. 2, 1997). Chittagong Hill Tracts Peace Accord. ucdpged.uu.se > full text.

[24]. Tripura, John. (2 $2^{\text {nd }}$ Dec 2019). CHT Accord: 22 years of Promises not Kept. The Daily Star. 


\section{Laws and Ordinances}

The Chittagong Hill Tracts Regulation, 1900 (Act No. I of 1900)

The State Acquisition \& Tenancy Act, 1950 (Act No. XXVIII of 1950)

The Chittagong Hill Tracts (Land Acquisition) Regulation, 1958 (Regulation No. 1 of 1958)

The Chittagong Hill Tracts Regional Council Act, 1998 (Act No. XII of 1998)

The Chittagong Hill Tracts Land Dispute Resolution Commission Act, 2001 (Act No. LIII of 2001)

The Chittagong Hill Tracts Regulation Amendment Act, 2003 (Act No. XXXVIII of 1900)

The Small Ethnic Minority Cultural Institution Act, 2010 (Act No. XXIII of 2010).

The Chittagong Hill Tracts Development Board Act, 2014 (Law No. 8 of 2014) 